(1)

\title{
The Tamil Proscriptions: Identities, Legitimacies, and Situated Practices
}

\section{Suthaharan Nadarajah}

To cite this article: Suthaharan Nadarajah (2018) The Tamil Proscriptions: Identities, Legitimacies, and Situated Practices, Terrorism and Political Violence, 30:2, 278-297, DOI: 10.1080/09546553.2018.1432214

To link to this article: https://doi.org/10.1080/09546553.2018.1432214

\section{(c) 2018 The Author(s). Published with license by Taylor \& Francis}

曲 Published online: 02 Mar 2018.

Submit your article to this journal $₫$

Џll Article views: 146

View Crossmark data

Citing articles: 1 View citing articles ¿ð 


\title{
The Tamil Proscriptions: Identities, Legitimacies, and Situated Practices
}

\author{
Suthaharan Nadarajah \\ Centre for International Studies and Diplomacy, SOAS University of London, London, UK
}

\begin{abstract}
Conventional analyses of terrorism proscription rely on conceptions of policy in terms of bureaucratic institutions and processes functioning according to means-end rationality, and law as an institutionalised body of rules expressive of sovereign power. By contrast, this article argues that the workings of Western terrorism proscription are inseparable from and deeply conditioned by situated interpretations of the contexts and dynamics within which West-led interventions for global stability-equated with liberal order-are pursued. Predicated on a seemingly self-evident division between "liberal" conduct, actors, and practices and illiberal ones which threaten the former, the production of good order requires the strengthening of the former, and the disciplining, transformation, or destruction of the latter. However, categorisations as "liberal" or "non-liberal" are not derived from "objective" criteria, but always mutually dependent on the situated interpretations by (self-recognised) liberals of the contexts within which they are intervening. Taking an interpretive approach that treats state action as situated practice, the article traces Western states' security engagement with Sri Lanka before, during, and after the armed conflict (1983-2009) to show how changing calculations for liberal peace there governed evolving proscription practices in relation to the LTTE and the Tamil diaspora.
\end{abstract}

\section{KEYWORDS}

Liberal order; situated practices; Sri Lanka; Tamil diaspora; terrorism proscription

\section{Introduction}

On April 1, 2014 the Sri Lankan government proscribed fifteen Tamil diaspora organisations as terrorists, alleging they were "fronts" for the Liberation Tigers of Tamil Eelam (LTTE), attempting to revive the movement after its destruction in 2009. Rationalising the bans on organisations such as the British Tamil Forum (BTF) and Global Tamil Forum (GTF) as intended "to combat terrorism and to control terrorist financing," the government invoked UN Security Council resolution 1373, which it pointed out is binding on all states. ${ }^{1}$

However, on the same day the UK rejected the proscriptions, saying it "has good relations with a wide range of ... civil society organisations with an interest in Sri Lanka, including the Global Tamil Forum and British Tamils Forum," and pointedly adding: "the UK will continue to engage with organisations focused on achieving a lasting and equitable peace in Sri Lanka through non-violent means." ${ }^{2}$ Canada, Australia, the United States, and the European Union responded similarly. ${ }^{3}$ Western states continued to interact with most proscribed Tamil diaspora organisations, including in joint advocacy 
at the UN Human Rights Council on accountability for mass atrocities during Sri Lanka's war. Western pressure led in 2015 to a new Sri Lankan government de-proscribing eight Tamil diaspora organisations, including BTF and GTF. Those still banned operate freely in the West.

The Western reactions to Sri Lanka's diaspora proscriptions represent something of a puzzle. First, the government's argument that these organisations were supporting the LTTE's revival was, on the face of it, not implausible. The Tamil diaspora had long been recognised as a key source of political, material, and financial support for the LTTE. ${ }^{4}$ It was recognised the LTTE's destruction had not extended to its international networks. ${ }^{5}$ Most diaspora organisations proscribed by Sri Lanka are explicitly supportive of an independent state of Tamil Eelam, and some were known to Western authorities for past links to the LTTE. ${ }^{6}$ Second, during the war Western governments themselves had been engaged, sometimes in coordination with the Sri Lankan authorities, in aggressively policing the Tamil diaspora to deter support for the LTTE and Tamil separatism; the U.S. and Canada had previously listed other diaspora groups as LTTE "fronts." "Third, as is now well documented, today's global counterterrorism efforts are governed by futureoriented logics of pre-emption, pre-crime, and risk. ${ }^{8}$ Fourth, UNSC 1373, adopted in 2001 under Chapter VII of the UN Charter, and described as the "cornerstone of the UN's counter-terrorism effort," 9 is binding on all states to, inter alia, "refrain from providing any form of support, active or passive, to entities or persons involved in terrorist acts"; "deny safe haven to those who finance, plan, support, or commit terrorist acts"; and "afford one another the greatest measure of assistance," including sharing evidence, in countering support for terrorism. ${ }^{10}$

The Tamil case highlights other paradoxes. Western support for Sri Lanka's counterinsurgency had been robust throughout the war, and untrammelled by state forces' persistent atrocities and rights abuses. ${ }^{11}$ Yet, Western states routinely acknowledged the LTTE had never targeted Western interests. ${ }^{12}$ The LTTE was proscribed by the U.S. in 1997, the UK and Australia in 2001, and Canada and the European Union in 2006. Despite the bans and aggressive policing, Tamil diaspora support for the LTTE continued and indeed visibly expanded in the final years of the war. ${ }^{13}$ Yet, there have been very few Western anti-terrorism prosecutions related to the LTTE, with most convictions resulting in light sentences. ${ }^{14}$ Even after the UK ban in 2001, a senior LTTE figure-its chief negotiator and political strategist, Anton Balasingham-continued to work from London until his death from cancer in $2006 .^{15}$

Mainstream analyses of terrorism proscriptions treat these as functional responses to self-evident threats faced by states or their allies. A significant seam of critical literature, accepting this basic means-end logic, has focussed on misuse, excesses, and policy contradictions-for example, disruptive impact on conflict resolution, peacebuilding, and humanitarian efforts in conflict zones, or distortion of law by unwarranted foreign policy considerations. Turning on questions of efficacy and effectiveness, and inconsistency and unevenness, both literatures treat law as a set of institutionalised rules expressive of sovereign power. In this way, analysis is divorced from the changing wider context in which counterterrorism practices, including those of proscription, unfold.

By contrast, this article suggests that paradoxes, inconsistencies, and unevenness such as those outlined above can be explained by locating evolving Western security practices explicitly within wider West-led efforts to produce in places like Sri Lanka 
what has been termed, as theoretical shorthand, liberal peace. ${ }^{16}$ Specifically, adopting an interpretive analytical approach ${ }^{17}$ and treating state action as always situated practice, ${ }^{18}$ it argues that Western security practices, here those related to terrorism proscriptions, are inseparable from and deeply conditioned by the everyday calculations inherent to generating global stability, equated with this specific social, political, and economic order. Liberal order-making is predicated on a seemingly self-evident division between liberal conduct, actors, and spaces and illiberal ones that threaten the former-a division informing and also reproduced in counterterrorism praxis itself, via related categories such as "moderate"/ "extremist." 19 However, categorisations of actors and actions as "liberal" or "non-liberal" are always argumentatively arrived at and mutually dependent on the situated interpretations-by (self-recognised) liberals-of the contexts and dynamics within which Western interventions for global stability unfold. Tracing Western states' security engagement with Sri Lanka before, during, and after the armed conflict (1983-2009), the article shows how changing calculations for producing liberal peace governed the West's proscription practices.

The analysis below is guided by two separate but inter-related questions. First, why did Sri Lanka's proscription of Tamil diaspora groups in 2014 appear so self-evidently unjustifiable as to warrant summary dismissal by leading states in the "War on Terror," given the long history of their own counterterrorism practices in relation to the LTTE and the Tamil diaspora? Second, why did proscription-as terrorists-of leading Tamil diaspora advocacy groups appear to the Sri Lankan government as self-evidently justifiable and necessary at this juncture, given their (now) "good relations" with Western "host" governments?

The article proceeds as follows. The first section elaborates the project of global liberal order-making, and how the liberal/illiberal divide on which it rests is also integral to the rise, well before 9/11, of the international (Western) counterterrorism architecture. The second section sets out a reading of terrorism proscriptions as situated practice, drawing on James Boyd White's conception of law as "constitutive rhetoric." ${ }^{20}$ The third and fourth sections trace the trajectory of Sri Lanka's war and the workings of international terrorism proscriptions within it. Rather than as an "internal conflict," the war is read as a space of transnational security contestation, in which a central stake is liberal order. Using the UK as representative example, the section shows how ambitions for liberal peace governed the evolving practices of Western counterterrorism, including proscription, in relation to Sri Lanka and the Tamil diaspora. The fifth section traces how as the war ended, evolving diaspora mobilisation and Sri Lankan state conduct served to dramatically alter Western foreign relations with Sri Lanka and, in particular, the premises -and therefore the practices-of Western counterterrorism policing of the Tamil diaspora. The article concludes by critically evaluating alternative explanations for this shift, and outlining some implications of its analysis.

\section{Proscription and the defence of liberal order}

The liberal triumphalism that followed the end of the Cold War reinvigorated ambitions for a world order predicated on liberal democracy, market economics, and rule of law. ${ }^{21}$ Liberal order-making had been continuous since the founding of the United Nations, shaping a Cold War world defined not only by super-power rivalry but also diverse 
relations between a U.S.-dominated liberal core and a less peaceful "free world" periphery. $^{22}$ Like the "War on Terror," the Cold War was hard fought both at home and abroad, generating both constant Western intervention in Third World conflicts and national preoccupations with military preparedness that had powerful transformative impact on their own societies. ${ }^{23}$ At the same time, interventions, such as in Vietnam, coproduced both the specific conception of liberalism that has since become taken for granted as the constitutive ideology of the West, and the logics of modernisation and pacification constitutive of ambitions for "liberal peace." 24

With the end of nuclear-armed super-power rivalry, "internal conflict" rose to prominence as a primary threat to the possibility of global liberal order, a view reinforced by the wars in the Balkans and genocide in Rwanda. ${ }^{25}$ At the same time, the liberal peace became "the dominant lens through which the broader world views conflict and its resolution." ${ }^{26}$ According to this view, whatever the specificities of a given conflict on liberalism's periphery, both peace and the path to achieve this comprise democracy, markets, and the rule of law. ${ }^{27}$ In this way, the liberal peace is "irrevocably linked to the territorially sovereign state as an umbrella for political community." ${ }^{28}$ Thus the start point for advancing liberal peace is to consolidate and defend the state, notwithstanding its own flaws, against diverse threats from both armed non-state challengers and "non-liberal"e.g., "ethno-nationalist," "fundamentalist," "separatist," etc.-political projects. As such, it was in the reinvigorated pursuit of global liberal order after the Cold War that diverse armed actors engaged in localised struggles began to appear for Western states as selfevident threats to international security. While the "Global War on Terror" is typically associated with confronting global Islamic insurgency, it was always a broader "civilising offensive" in militarised defence of global liberalism. ${ }^{29}$

Thus while today's global anti-terrorism architecture expanded rapidly after 9/11, its constitutive elements, including international terrorism proscriptions, had already emerged in the late 1990s (see below). This was a period defined by numerous West-led interventions in conflict zones around the world, through themes such as peacebuilding, peacekeeping, securitised development, economic liberalisation, security sector reform, etc., and, later, "humanitarian intervention." The case of the UK is illustrative. From the earliest years of the Blair government (1997-2007) the centrality of liberal order-making to UK foreign policy was underlined by creation of the cabinet-level Department for International Development (DFID) with a ring-fenced, multi-billion-pound budget, and "humanitarian interventions" in Sierre Leone and Kosovo. In that sense, the expansion of Western security governance (counterterrorism) to distant warzones-of which policing diasporas at home is integral part ${ }^{30}$ - was inseparable from a radical post-decolonisation recasting of state sovereignty, ${ }^{31}$ even if this was not immediately apparent to states such as Sri Lanka drawing increased Western support for their own local "wars on terror."

It is in this liberal interventionist context that the dramatic rise of Western proscriptions of "international terrorism" after the Cold War should be located. In 1997, for the first time, the U.S. banned almost thirty armed groups worldwide as "Foreign Terrorist Organizations." In early 2001 the UK similarly proscribed 21 groups under the new Terrorism Act 2000. There were some differences-for example, the LTTE, ETA in Spain, and GIA in Algeria, along with Al Qaeda, were on both lists, while Hamas, Hezbollah, and FARC were on the U.S. list, but not the British one. However, what is significant is how the idea of proscription at home as integral to producing peace and 
security elsewhere had become uncontroversial amongst Western policy-makers, legislators, and publics. In this emerging commonsense, what constituted "terrorism" was also self-evident, even if some banned groups had no history of violence against the U.S. or the UK, and their political agendas posed no obvious threat to national security; rather, it derived from a self-evident global divide between liberal ("civilised") conduct and spaces and illiberal ones that threatened the former-a division also reproduced in and through counterterrorism praxis itself, via related categories such as "moderate"/"extremist," "democratic"/"authoritarian," etc. ${ }^{32}$

In that sense, the Terrorism Act 2000-then the "state of the art" in anti-terrorism legislation $^{33}$-represented the coming of age of domestic terrorism law as a modality of transnational governance of global disorder. Despite the UK's long history of antiterrorism efforts-in Ireland, other colonies, and then Northern Ireland-reference to "international" terrorism first entered UK law in the 1984 update of the Prevention of Terrorism Act (PTA), and developed in the 1989 update. $^{34}$ However, as Jessie Blackbourne's study shows, at each revision, the government's assertions of a rising threat from "international terrorism" was not supported by the available data. ${ }^{35}$ The Terrorism Act 2000 was enacted by the Blair government, but it was the product of a wholesale rethinking of terrorism law initiated in 1995 by the previous Conservative government. ${ }^{36}$ Notably, the explicit assumption for Lord Lloyd's review was that of lasting peace prevailing in Northern Ireland, and its overwhelming focus was on dealing with "other terrorism." 37 In contrast to previous legislation, the entire Terrorism Act 2000 applied to all types of terrorism-domestic, international, and Northern Ireland (though political violence in Northern Ireland has since been addressed through ordinary criminal law). Moreover, after 28 years the definition of terrorism had changed, expanding motivation for terrorism from "political ends" to "advancing a political, religious or ideological cause." $^{\text {38 }}$

From the outset the conflict transformation and liberal peace logics inherent to Western terrorism proscriptions were explicit. As the U.S. State Department puts it, "FTO designations play a critical role in our fight against terrorism and are an effective means of curtailing support for terrorist activities and pressuring groups to get out of the terrorism business." ${ }^{39}$ It is in this way that proscription is twinned with the possibility of deproscription. For example, an often-repeated U.S. policy stance during the Norwegianled peace process in Sri Lanka (2002-2006) was, as Deputy Secretary of State Richard Armitage stated in 2003: "Our position is crystal clear. The LTTE must unequivocally renounce terrorism in word and deed if we are to consider withdrawing the [terrorist] designation." ${ }^{40}$ He elaborated in another speech what exactly this entailed:

The United States is greatly encouraged that the LTTE has made a commitment to the political solution; it has agreed to settle this conflict through peaceful means. We urge the LTTE to ... add to this commitment a public renunciation of terrorism and of violence-to make it clear to the people of Sri Lanka and indeed to the international community that the LTTE has abandoned its armed struggle for a separate state; and instead accepts the sovereignty of a Sri Lankan government that respects and protects the rights of all its people. ${ }^{41}$

The article traces below this central rationale (liberal order-making) in the dynamics of Western counterterrorism in relation to Sri Lanka. But the key point here is that terrorism proscriptions work by design as a disciplinary modality of transnational security 
governance, regulating the conduct of diverse actors and constituencies in the West and non-West-including states, diasporas, armed groups, etc.-towards the production of global order. ${ }^{42}$ For example, the stated purposes of U.S. FTO designations include: "stigmatizes and isolates designated terrorist organizations internationally; deters donations or contributions ...; heightens public awareness and knowledge of terrorist organizations; and signals to other governments our concern about named organizations." ${ }^{33}$

\section{Terrorism law as constitutive rhetoric}

Proscription is, at base, an act of law. From this start point, a great deal of scholarly and policy critique of Western proscriptions has elaborated the consequences of bans, not only for the listed organisations, but also a wide range of other actors, constituencies, and political projects, both in the West and in distant conflict spaces. Critiques of Western proscriptions have focussed on, for example, their negative impact on civil liberties and dissent, community relations, and diaspora politics at home, ${ }^{44}$ and on humanitarian and conflict resolution efforts abroad. ${ }^{45}$ However, with some exceptions, ${ }^{46}$ these works take for granted the liberal separation between violence and politics, and proscription is critiqued in ways that presuppose and thus reproduce the normative superiority of liberal forms of political and social conduct and order. In these ways, what is lost is the essential logic of terrorism proscription-as first and foremost an intervention for preferred (i.e., liberal) outcomes to violent political contestation in distant spaces.

This is not to argue against liberalism per se, but a reminder that the advance of liberal order, of which proscriptions play integral part, is invariably secured by strengthening one "non-liberal" project against other, even "less liberal" ones. ${ }^{47}$ As Kimberly Hutchins points out, liberalism "operates on the fundamental premise that some subjects are closer to being liberal than others," with human progress entirely reliant on the agency of (more) liberal subjects. ${ }^{48}$ Proscription in the context of liberal order-making, therefore, is about strengthening some not-so-liberal subjects (such as the flawed states of the global South) against even less liberal ones (such as their "terrorist" challengers).

In the analysis here liberalism is treated as a political rationality, rather than a philosophy, theory, or ideology. ${ }^{49}$ A political rationality, in and of itself, does not prescribe exact policies or practices for achieving the social order which is predicated on it. Rather, it defines "the problem-space" of order-making in ways that make the regulation of political, social, and other conduct intelligible, calculable, and "practicable." Consequently, perceived problems for liberal ends, for example, invoke diverse practices and policy responses that are both contingent on the situated calculations of, and debates among, (self-recognised) liberal agents and at times contradictory-for example, both supporting and opposing self-determination struggles, deploying and eschewing the use of force, etc.

Such governing calculations are as integral to the "rule of law" as any policy domain. For example, that an organisation is proscribed does not mean arrests for known acts of support will always follow. Rather, just like proscription (and de-proscription) itself, such decisions are always governed by perceived prevailing circumstances in relation to wider order-making ambitions. By way of illustration, in July 2001 LTTE fighters attacked Sri Lanka's international airport in Colombo, also the military's main airbase. The raid destroyed or badly damaged 13 aircraft, including five airliners of the national carrier, 
making it historically the largest attack on civilian aviation. Yet, when Canada and the EU published lists of banned terrorist organizations after 9/11, the LTTE was notably absent, an exemption clearly linked to its participation in the emergent Norwegian-led peace process (see below). The EU and Canada only banned the LTTE in 2006, after the peace process had irretrievably collapsed.

To see such "external" considerations in relation to terrorism proscription as inconsistency in or even distortion of law is to rely, first, on a specific, albeit widely taken for granted, understanding of law as a set of institutionally established and managed, and more-or-less determinate, body of rules; and, second, a conception of the policy world wherein law operates in Weberian terms of bureaucratic institutions and processes functioning according to means-end rationality. ${ }^{51}$ By contrast, James Boyd White argues law should be conceived as a rhetorical activity, and in particular as "constitutive rhetoric." 52 By this he means, first, law is always an irreducibly argumentative activity; that is, law always works by a process of translation "from ordinary language to legal language and back again." ${ }^{3}$ Second, law "is at once a social activity-a way of acting on others - and a cultural activity - a way of acting with a certain set of materials found in culture" (see below). ${ }^{54}$

Thus, law is not experienced as an independent system of meaning, but is always contextualised in "culture-specific" and "socially specific" ways. By this White means, respectively, law always "takes place in a particular social context, in which it is also an intervention," 55 and "always starts with an external empirically discoverable set of cultural resources into which it is an intervention." ${ }^{56}$ Such resources "include rules, statutes and judicial opinions, but much more as well: maxims, general understandings, conventional wisdom and all other resources, technical and non-technical" that might be used, for example, in defining and arguing one position or another. ${ }^{57}$ Consequently "the identity, the meaning, and the authority of these materials are always arguable, always uncertain." 58 At the same time, law also constitutes both the community and the materials making up the culture it commends-for example, terrorism proscription regimes constitute subjects as "terrorists," "counter-terrorists," "supporters of terrorism," etc. ${ }^{59}$ As discussed below in relation to terrorism proscription, Sri Lanka and the Tamil diaspora, the categories of "liberal" and "non-liberal" inherent to the everyday workings of Western terrorism proscription (for example, informing categorisations as "moderate"/"extremist," or "democratic"/“authoritarian") are neither self-evident nor static but contingent and coconstitutive of the very security practices they call up.

In sum, necessarily working "through speakers located in particular times and places speaking to actual audiences about real people" and in "language that is continuous with ordinary language," law is "perpetually reaffirmed and rejected in a social process." 60 Created and recreated out of everyday practices that derive from the prevailing context and culture, and the argumentative reconstitution of this culture and the rhetorical community itself, law should be understood not simply as a set of institutionally established and managed body of rules, but socially and culturally situated rhetorical life. ${ }^{61}$

Sri Lanka provides an illustration. The armed conflict there grew directly out of the ethno-political crisis that emerged with independence from Britain in 1948, as majoritarian nationalism drove the country's rapid transformation into a Sinhala-Buddhist ethnocracy in the next two decades. ${ }^{62}$ Tamil resistance manifested in persistent mass protest and civil disobedience, and a demand for federal autonomy. With the passing of the 1972 
Sinhala-Buddhist constitution, this turned into a demand for an independent Tamil Eelam, articulated by a union of major Tamil parties that then swept the Tamil areas in the 1977 elections. The government responded by deploying the armed forces, and passing the Prevention of Terrorism Act (1979). Thus, in a discursive conflation that endures to the present, Tamil separatism was equated with terrorism as an existential threat to Sinhala-Buddhist national and state order. ${ }^{63}$ For example, the government's response to the shock of the LTTE's first major attack in July 1983 (an ambush that killed 13 soldiers) was not to ban the LTTE itself, but to pass the 6th amendment to the constitution. This states, on threat of severe punishment:

(1) No person shall, directly or indirectly, in or outside Sri Lanka, support, espouse, promote, finance, encourage or advocate the establishment of a separate State within the territory of Sri Lanka. (2) No political party or other association or organization shall have as one of its aims or objects the establishment of a separate State within the territory of Sri Lanka.

Thus what constitutes terrorism is hardwired into the constitution-as separatism. While Sri Lanka's war is typically dated from 1983 to 2009, the LTTE itself has been proscribed there for only five of those years: 1998-2002 and since 2009. Nonetheless, throughout the war, and since, the draconian PTA has been used extensively, generating tens of thousands of detentions-and widespread rights abuses enabled by the impunity it provides. ${ }^{64}$ Support for terrorism in Sri Lanka, both in and beyond the law, is not just about violence but separatism-or as current President Maithripala Sirisena terms it, "LTTE ideology." ${ }^{65}$ It is in this long-prevailing commonsense that the 2014 proscriptions of Tamil diaspora organisations-as terrorists-was a self-evidently appropriate state response to their expanding international political advocacy (cf. the reference to "in or outside Sri Lanka" in the 6th amendment). The article returns to this after examining the role of terrorism proscriptions in long-running Western efforts to generate (liberal) peace in Sri Lanka.

\section{Defending liberal order in Sri Lanka}

In July 1983 Sri Lanka's worst anti-Tamil pogrom, which followed the LTTE's first attack, triggered all-out war between a hitherto low-grade but now expanding Tamil insurgency and state forces. The war escalated relentlessly, despite for four abortive peace processes, until the LTTE's defeat in 2009. From the outset, however, Sri Lanka's counter-insurgency was an explicitly transnational project, to which the UK and U.S., in particular, were integral. In 1979, five years before the war but amid deepened ethnic tensions following the 1977 elections, Britain sent a former MI5 director with experience of Northern Ireland and Malaya to advice on the "total reorganisation" of Sri Lanka's intelligence apparatus in light of the "Tamil problem." ${ }^{36}$ When war began, Britain-acting through private military companies-helped establish a specialist counterinsurgency police force, closely modelled on experiences in Northern Ireland. ${ }^{67}$ The U.S. also took a prominent role, with training and arms provided-given Indian Cold War sensitivities-through Pakistan, Israel, South Africa, and private military companies, whose personnel also participated in operations. ${ }^{68}$ After the Cold War, Western involvement expanded through direct military assistance and later active co-operation (see below). 
This Western involvement turned on an enduring reading of Sri Lanka and its crisis that located these on the frontier separating liberal and non-liberal worlds. During the Cold War, despite its intensifying ethnic crisis, Sri Lanka was a self-evident part of the "free world," a parliamentary democracy with historical close ties to the West. Moreover, President Junius Jayawardene's government (1977-1989) was a poster-child for the neoliberal economic reforms being promoted by the IMF and U.S. and UK governments. ${ }^{69}$ As British Premier Margaret Thatcher stated during a 1985 visit to Colombo:

Sri Lanka is a democracy, the United Kingdom is a democracy... . Everyone in Northern Ireland has the same right to vote and ... everyone here has the same right to vote, and therefore terrorist movements are aimed at upsetting democracy and imposing a rule by force. That is why one must see that terrorist movements do not succeed in democratic countries. ${ }^{70}$

Two decades after Thatcher's speech-and long after the UN had ranked Sri Lanka as second only to Iraq in the number of enforced "disappearances"-U.S. UnderSecretary of State Nicholas Burns stated during a 2006 visit to Colombo, in comments representative of broader Western policy:

We are a great friend to this country. We support its territorial integrity. We support the preservation of peace... . The government is democratic... . It's a responsible government, dealing with enormous challenges, [including] the effort to provide economic growth, but particularly the fight against terror [and] to preserve peace ... Our major concern is with the LTTE. There is no moral comparison, no moral equivalency that we see between the government and the LTTE ... [a] reprehensible terrorist group keeping this country verged on the edge of war. ${ }^{71}$

In short, the war in Sri Lanka was always read, and discursively produced, in Western policy as a frontline in the global defence of liberal peace; on one side was a flawed/ emerging market democracy, and on the other, a violent ethno-nationalist separatist threat. The former therefore constituted the latter as terrorism. Nonetheless, the country's deep-seated ethno-political tensions could not be denied. In this regard, the liberal reading of successive Sri Lankan governments turned on their stated willingness to address Tamil "grievances" through negotiated constitutional change and liberal reform. That is, a solution acceptable to "all Sri Lankans" was self-evidently possible through negotiation and democratic process, if only the LTTE was willing to cooperate.

Consequently the LTTE's resilience against ever-expanding counterinsurgency exacerbated an inescapable dilemma in Western aspirations for liberal peace in Sri Lanka: on the one hand, the need to reinforce and defend the state against the LTTE ("defeating terrorism"), and on the other, the need to produce a negotiated "political solution" to the ethno-political crisis (i.e., power-sharing and liberal reform). It is within this dilemma, which endured to the end of the war and continues in a different form today (see below), that the uneven and inconsistent trajectory of Western proscriptions related to the LTTE can be read.

\section{Proscriptions during Sri Lanka's war}

Until the mid-1990s, negotiations with Tamil militants were considered unavoidable for stabilising Sri Lanka. This was complicated by India's changing role in the conflict. At first, 
India supported the Tamil insurgency with arms, training, and basing-with a view to dissuading Colombo from its pro-U.S. stance in the Cold War. ${ }^{72}$ In 1985 India brokered abortive peace talks. In 1987 Delhi intervened militarily, coercing Colombo into signing the Indo-Sri Lanka Accord, which established (thin) provincial autonomy. However, when India sent peacekeeping troops to disarm the militants, protracted fighting ensued. During this the LTTE began peace talks with a new Sri Lankan government also keen to end the Indian presence. After Indian forces withdrew in 1990 the talks collapsed and war resumed.

Amid the above-mentioned dilemma, in the first decade or so of war, a clear contradiction operated in Western policy. On the one hand, there was extensive assistance for Sri Lanka's vicious counterinsurgency; on the other hand, Tamil militant groups were permitted to conduct political activity and fundraising in Western countries, albeit under close surveillance. For example, the LTTE maintained its International Secretariat in London until it was banned in 2001. The growing base for this political activity was the steady inflow of Tamil refugees which, starting after the 1983 pogrom, contributed over the next three decades to today's settled diaspora of a million people. However, even well before the war, alongside developing Sri Lanka's intelligence apparatus, Britain's security services were, as Premier Thatcher assured the Sri Lankan government in 1981, keeping a "close eye" on Tamil diaspora activism. ${ }^{73}$ Later they also kept watch on-as well as contact with-the Tamil militant groups' elements in the UK. ${ }^{74}$

In 1995 a new Sri Lankan government that explicitly adopted the rhetoric of liberal peace, and its plan to twin military destruction of the LTTE with negotiations with "moderate" Tamil parliamentary leaders offered a new way forward for the liberal project. Western economic and developmental aid increased and the U.S., in particular, stepped up military support for the government's self-styled "war for peace." The U.S. proscribed the LTTE in 1997. The UK ban followed under the new Terrorism Act 2000. Sri Lanka, meanwhile, proscribed the LTTE in 1998. As military operations intensified, and parliament debated the "devolution package," Western governments also began to harden their approaches to the Tamil diaspora. For example, in 1996 the Australian government refused to meet with Tamil groups unless they disavowed the LTTE. In short, through the lens of liberal peace, the Tamil diaspora began to appear more clearly, alongside the LTTE, as a distinct threat. ${ }^{75}$

However, what is significant was the lack of direct action-for example, through arrests -against pro-LTTE activism. Instead, Western policing worked outside formal legal mechanisms, using the threat of legal action to pressure Tamil diaspora groups into eschewing separatism and the LTTE, and instead supporting the Sri Lankan government's devolution talks with Tamil political parties. $^{76}$

The stalling of Sri Lanka's military campaign and related expansion of the LTTE into a "de facto" state in areas under its control ${ }^{77}$ necessitated a change in strategy. The result was the West-backed Norwegian peace initiative from 2000, centred on negotiations with the LTTE, rather than with "moderate" Tamil parties (which also united in endorsing the “extremist” LTTE as representing Tamils' interests in talks). Despite Sri Lanka's customary objections to international mediation as "foreign interference" in "internal affairs," further battlefield setbacks and a cut in donor aid compelled the government to accept Norwegian brokering. This produced a ceasefire in February 2002. It is amid this shift from counterinsurgency to peace process for advancing liberal peace in Sri Lanka ${ }^{78}$ that the LTTE was 
conspicuously absent from EU and Canadian proscriptions after 9/11 (see above). Moreover, when the LTTE insisted the Sri Lankan government lift its ban as a precondition for talks, the U.S. and UK-while maintaining their own bans-pressured Colombo to acquiesce. Sri Lanka lifted its ban in September 2002 and talks followed. The peace process was formally backed by the quartet ("Co-Chairs") comprising the U.S., the EU, Japan, and Norway.

This is not to suggest Western neutrality; rather, the overriding priority was stopping the stalemated yet destructive war and preventing its resumption while engineering a "political solution" that would advance liberal reform and (thus) defuse Tamil separatism. To this end, even as Norway introduced federalism as basis for negotiations, the U.S. oversaw a wholesale reconstitution of the Sri Lankan armed forces. As U.S. Ambassador Jeffrey Lunstead put it, "as part of its strategy for promoting the peace process, the U.S. began to strengthen its military relationship with Sri Lanka."79 In the first year of ceasefire, the navy and air force doubled in size. The army expanded by a third, tripled its artillery, and doubled its tank numbers. ${ }^{80}$ The U.S. overhauled the military's communication and radar networks and donated a warship for deep-sea interdiction of LTTE supplies. ${ }^{81}$ Thus, military assistance and terrorism proscription (both threats of further bans and conditional offers to lift extant ones) together made up a "carrot-and-stick" framework to compel the LTTE to stay in the peace process and ultimately "renounce terrorism in word and deed" (see above).

This disciplinary logic of conflict transformation also governed Western security practices at home. It was recognised that the staying of the EU and Canadian bans permitted LTTE fundraising (but this was more than offset by Sri Lanka's emergent military capabilities). In the UK fundraising also continued despite the ban, albeit more discreetly. It is not that British security agencies were unaware terrorism laws were being broken-as they routinely made clear in meetings with LTTE representatives in UK. Rather, Western policy emphasis was on not undermining the West-underwritten peace process by the inevitable controversy that anti-terrorism arrests would generate. ${ }^{82}$ Instead Western policing worked through less high-profile actions - searches of Tamil businesses, actions at border control, surveillance of protests, etc.- to maintain a hostile climate for pro-LTTE activism; in response Tamil groups self-regulated their public statements, publications, and events to avoid (what might be constructed as) breaches of anti-terrorism law. ${ }^{83}$

Negotiations stalled in 2003 and despite Norwegian efforts the peace process eventually collapsed under escalating tit-for-tat violence between both sides' intelligence arms. In early 2006, this "shadow war" segued into all-out war as Sri Lanka's reconstituted military launched a massive military campaign, robustly backed by Western states. The U.S., for example, supplied "real-time" satellite intelligence. ${ }^{84}$ The EU and Canada now banned the LTTE. In 2007, the first Western anti-terrorism arrests related to the LTTE followed-three people in Australia (May), four in Britain (June), and eight in the U.S. (August). In November both Sri Lanka and the U.S. proscribed the largest Tamil charity, the Tamil Rehabilitation Organisation-which in 2005 had won an award from the Colombo government for its work after the Indian Ocean tsunami. The explicit governing logic of these actions was to compel the LTTE to abandon its armed struggle and accept Sri Lanka's sovereignty and a "political solution" on the government's terms. However, the LTTE continued its armed struggle until it was destroyed in 2009. 
Tamil separatism became mainstream in Sri Lanka years before Tamil insurgency emerged as a major threat to the state. However, in Western security practices over three decades these were always treated as one and the same. This not only informed but was produced through proscriptions of the LTTE and the related policing of the Tamil diaspora. However, the next section traces some unexpected and significant developments from the war's final months in Western states' relations with the Tamil diaspora and with Sri Lanka.

\section{Proscription after Sri Lanka's war}

The way in which Sri Lanka's war ended had significant consequences for relations between Western governments and the Sri Lankan government, and between the Tamil diaspora and their "host" governments. In short, amid disintegrating possibilities for liberal peace in Sri Lanka, the positions of the state and the diaspora gradually reversed along the liberal/illiberal divide. The state, long been considered a willing agent of liberal peace, emerged as a recalcitrant obstacle, and thus the primary target of forceful Western reformist efforts. Relatedly, the long-standing premise of Western anti-terrorism policing -that the Tamil diaspora was a threat to liberal peace in Sri Lanka-disappeared as diaspora organisations, whilst still avowedly nationalist, nonetheless became incorporated into the international liberal order-making policy nexus. This section discusses these dynamics in relation to the working of terrorism proscription regimes.

By January 2009 it was clear that the LTTE, despite its fierce resistance, was on the verge of defeat. Western governments called for a surrender, but also for a "political solution" to secure lasting peace. Rejecting the latter as "intrusion in Sri Lanka's internal affairs," the government banned the LTTE. ${ }^{85}$ The military intensified its offensive on LTTE-controlled areas, with mass bombardment of civilian concentrations, hospitals, and the government's own designated "no fire zones." Alarmed by the unfolding carnage, Western governments called for a temporary "humanitarian" ceasefire. Colombo rejected this as "ridiculous" and a "transparent attempt to save the Tigers." The British and French Foreign ministers rushed to Colombo, but were rebuffed, ${ }^{88}$ as was U.S. President Barack Obama, who, warning of a humanitarian "catastrophe," directly called on the government to "stop the indiscriminate shelling ... including [of] hospitals." 89 UN investigations later estimated at least 40,000 Tamil civilians were massacred in the final five months. ${ }^{90}$

Thus, even as the war ended it was clear the liberal project in Sri Lanka was in crisis. This worsened amid the Sinhala-nationalist triumphalism that followed the government's victory. Despite vocal international criticism, the entire surviving population of the former LTTE-controlled area-over 330,000 people-were interned in militarised camps for up to two years, and endured widespread rights abuses, including summary executions, "disappearances," torture, and rape. ${ }^{91}$ In this way, mass atrocities and rights abuses opened a key fault line in Sri Lanka's relations with Western states. Even as the war ended, the UK and other EU states were calling for independent investigations into war crimes. Meanwhile, it was noted the U.S. avoided congratulating the Sri Lankan government on its victory; only stating it "welcomes the fact that the fighting has ended, and [is] relieved that the immense loss of life and killing of innocent civilians appears to be over." 92 The U. S. also again called for "a political arrangement that promotes and protects the rights of all 
Sri Lankans." Rejecting this as unnecessary, precisely as the LTTE was no more, the government also repudiated the broader liberal reform and peace agenda. ${ }^{93}$

Meanwhile, from January 2009 demonstrations by diaspora Tamils erupted in several Western capitals. This mobilisation was different-in scale, tactics, and compositionto previous diaspora activity. ${ }^{94}$ In the UK, for example, thousands of Tamil protestors began in April an illegal occupation of Parliament Square that lasted till mid-June. Two (permitted) marches in January and April each drew over 100,000 people. ${ }^{95}$ Diaspora anger was directed both at the Sri Lankan government and "their" governments which, having long condemned the LTTE as terrorists, seemed either unable to stop the ongoing mass atrocities or, as was widely perceived, indifferent to these so long as the LTTE was destroyed. As the legitimacy of Western governments collapsed in this way, so did the disciplinary purchase of their terrorism proscriptions. Diaspora protests everywhere explicitly foregrounded not only Tamil nationalist themes, including demands for Tamil Eelam, but in open defiance of the ban, overt support for the LTTE's armed resistance. Also novel, there were frequent clashes between Tamil demonstrators and police. Yet the febrile context, i.e., that of Sri Lanka's mass killings, was well recognised by police authorities and governments. In the UK, for example, while there were frequent arrests at the unlawful occupation outside parliament, most were soon released; there were no prosecutions either under public order or antiterrorism laws.

It is in this context that in April, the UK's sole LTTE-related prosecution to date came to trial. ${ }^{96}$ The case illustrates proscription as always situated practice. Arunachalam Chrishanthakumar, a prominent Tamil activist, had been arrested in 2007, along with three others whom the jury acquitted, and charged with purchasing electrical equipment for the LTTE in 2004. Although UK authorities were aware of his actions at the time (i.e., during the peace process), rather than arrest him, they had warned him to stop. At the trial the defence argued Chrishanthakumar had been assisting the LTTE's civil administration, not its armed struggle. Former British development Secretary Clair Short, appearing as witness for the defence, confirmed UK aid had also been sent to LTTE-held areas at the time. To the defence's argument the LTTE should not be considered a terrorist organisation, the judge said that was "a matter for parliament," but "the [UK] terrorist law has to be obeyed as part of our obligations internationally." However, the judge said, although the offenses were "very serious," the case was "exceptional" because the LTTE was not banned in Sri Lanka at the time. Expressing "regret" he had to impose a jail sentence (two years including time served), the judge described Chrishanthakumar as "a thoroughly decent man who deliberately broke the law in support of a cause he fervently believed in," and that he hoped on his release he would "resume the humanitarian work you undoubtedly do."

Unlawful protests stopped with the war's end, but diaspora political activity expanded, as new organisations emerged, alongside those hitherto at the forefront of diaspora advocacy. ${ }^{97}$ Notably, whereas previous advocacy centred on endorsing the LTTE as representatives of Tamil political aspirations, in the post-LTTE context the new diaspora advocacy, while also avowedly Tamil nationalist and separatist, engaged Western governments on specific policy issues related to Sri Lanka. ${ }^{98}$ These included mass internment in military-run camps, humanitarian crisis in Tamil areas, and, in particular, accountability for wartime mass atrocities and ongoing rights abuses. In this way, policy interactions 
between Tamil diaspora organisations like the BTF and GTF, and Western governmentsincluding at cabinet level-became routine.

From 2010 the theme of "accountability," and specifically an international investigation into war crimes and rights abuses in Sri Lanka, drew together a broad, if fractious, coalition comprising international human rights groups, Tamil diaspora organisations, and Western governments. The Sri Lankan government's defiant rejection of any wrong-doing by its forces, and its hostility and threats towards the diverse accusers, contributed to a deepening rift with its former allies in the war against the LTTE. This came to fore in a series of resolutions against Sri Lanka at the UN Human Rights Council, sponsored and strongly backed by the U. S., UK, and other Western states, in March of 2012, 2013, and 2014. At each session in Geneva, lobbying of member states to support the resolutions was jointly conducted within the UN building-and the UNHRC chamber itself-by Western diplomats, international rights groups, and Tamil diaspora organisations. In Sri Lanka this West-led push for accountability was understood, in both popular Sinhala-nationalist discourse and government policy, as diaspora-driven, and therefore a serious threat to the country's sovereignty and territorial integrity. As then senior Minister (now President) Maithripala Sirisena put it in 2012:

If UNHRC implements the [resolution] presented by the U.S. regarding the alleged human rights violations in Sri Lanka, it will result in the division of the country. The U.S. is ... presenting false allegations against Sri Lanka with the aim of granting a part of the country to ... terrorist agents in certain Western countries. They are trying to revive terrorism in Sri Lanka. So, it is our duty to stand united against these foreign elements in order to protect our independence. ${ }^{99}$

The stakes rose significantly with the March 2014 resolution, which proposed an independent UN investigation into wartime atrocities. Despite lobbying by a 50-strong Sri Lankan delegation, including several ministers, and strong resistance by China, Pakistan, India, and other allies, the resolution was passed. From Colombo's perspective, this clearly showed the potency of the threat posed by Tamil diaspora organisations- "LTTE fronts." Accordingly, a week after the UNHRC vote, Sri Lanka proscribed fifteen diaspora organisations as terrorists, invoking UNSC 1373.

However, the same context that prompted this also produced Western governments' summary rejections of the bans. Justifying its response, the UK said it is "not aware of evidence that Tamil community organisations currently operating in the UK are engaged in terrorist activities," and that it had "[made] clear [to Sri Lanka] that proscription should not be used to prevent or stifle free speech and legitimate criticism." 100 Canada, Australia, and the UK also issued travel warnings to their citizens, pointing out that Sri Lanka's Prevention of Terrorism Act permits prolonged detention without charge or trial, and advising them to contact their embassies if arrested. ${ }^{101}$ Thus, rather than criminalising the diaspora organisations, the Sri Lankan government's proscriptions furthered its own alienation from Western governments. When Sirisena assumed the presidency in January 2015, one of his administration's first moves to rebuild relations with Western states was to announce a "review" of the bans, and later to de-proscribe eight of the organisations. ${ }^{102}$

\section{Conclusion}

Conventional analyses treat terrorism proscriptions as functional responses to armed threats to states or their allies. On this view, the prosaic explanation for Western states' 
summary rejections of Sri Lanka's proscriptions of Tamil diaspora organisations is that the LTTE's destruction had decisively ended the armed Tamil separatist threat to Sri Lanka's sovereignty and territorial integrity, and the government offered no evidence that the banned organisations were involved in reviving the LTTE. However, years after the war's end Western states continue to assert the LTTE remains a threat, not least because its international networks are intact. ${ }^{103}$ All Western bans on the LTTE continue-including the EU ban, despite its annulment in July 2017 by the European Court of Justice. ${ }^{104}$ Meanwhile, separatist mobilisation in the Tamil diaspora has never been higher than in recent years-in a context where Western counterterrorism practices work in futureoriented logics of pre-emption, pre-crime, and risk, and throughout the war Tamil separatism having served as the key indicator for Western authorities of support for the LTTE, i.e., terrorism.

Other explanations in mainstream commentary in Sri Lanka rely on instrumental calculations "external" to terrorism law. One is geopolitical: Western governments "sided" with the Tamil diaspora because of the then Sri Lankan government's leaning towards China. However, when a new "pro-West" government took charge in 2015, continuing Western pressure compelled it to de-proscribe some diaspora organisations, and those still banned operate freely in the West. In any case, against the diversity of Western states' policies towards China, there is considerable commonality in their positions on the Tamil diaspora (before and after the key change discussed above). It is also questionable whether desire for "regime change" in Sri Lanka could prompt the UK, the U.S., Canada, Australia, and the EU to refuse to abide by Sri Lanka's invocation of UNSC resolution 1373, the putative "cornerstone" of UN counterterrorism efforts. Another explanation is that Western politicians are wary of alienating voters amongst the sizeable Tamil diaspora. However, throughout three decades of war electoral considerations did not prevent Western governments of different hues from aggressive counterterrorism policing of the Tamil diaspora (with attendant ethnic profiling), denunciations of Tamil demands for independent statehood, and proscriptions of the LTTE.

Such explanations rely on conceptions of the policy world in terms of bureaucratic institutions and processes functioning according to means-end rationality, and of law as an institutionalised set of rules. By contrast, this article emphasised the utility of an interpretive approach that treats state action as situated practice. To summarise the argument; the workings of Western counterterrorism regimes are inseparable from and conditioned by the everyday calculations inherent to wider Western efforts towards global stability, equated with a specific social, political, and economic order, liberal peace. Predicated on a seemingly self-evident division between "liberal" conduct, actors, and practices and illiberal ones which threaten the former, the production of good order requires the strengthening of the former, and the disciplining, transformation, or destruction of the latter-although this is invariably attempted by strengthening some "nonliberal" subjects (such as the problematic states of the global South) against other, even "less liberal" ones (such as their "terrorist" challengers and those who support them). In this way, the liberal/illiberal divide is integral to the everyday workings of terrorism proscription regimes. However, categorisations of actors, actions, and positions as "liberal" or "non-liberal" are always argumentatively arrived at and mutually dependent on the situated interpretations-by (self-recognised) liberals-of the contexts and dynamics within which they are intervening. 
Key to explaining the post-war shift in Western counterterrorism vis-à-vis Sri Lanka is how amid intensifying state resistance to and increasing Tamil diaspora engagement in liberal reformist efforts there, their respective positions gradually reversed along the liberal/illiberal divide governing international order-making. Readings within Western policy praxis of the government (from "democratic" to "authoritarian") and Tamil diaspora organisations (from "terrorist fronts" to "civil society with an interest in Sri Lanka") do not derive from "objective" criteria but are discursively re/constructed within the thick transnational interactions and contestations that also reconstitute Sri Lanka as a frontline in the advance/defence of global liberalism.

Rather than as a set of institutionalised rules underpinned by sovereign power, the article treated law as socially situated and constitutive rhetoric, and therefore as "perpetually reaffirmed and rejected in a social process." ${ }^{105}$ Indeed, the Tamil case shows how sovereignty itself is made and unmade through the act of proscription. Western states' summary rejections of Sri Lanka's proscriptions of Tamil diaspora organisations is an example. Another is how Western proscriptions, powerful anti-terror laws, and policing interventions did not prevent large numbers of otherwise law-abiding citizens-diaspora Tamils-from continuing to provide the LTTE with material assistance and ultimately mass demonstrations of public support in defiance of sovereign power. Always criminalising armed violence ("terrorism") and associated political goals ("extremism"), proscriptions codify antagonistic relations between states and sections of their societies. However these relations are always overdetermined, evolving within the transnational interactions and contestations constituting conflict spaces that also govern when terrorism laws are obeyed or defied, to whom or what they are considered applicable, and indeed whether or not they are enforced.

Consequently, explaining the seeming paradoxes, inconsistencies, and unevenness in the workings of terrorism proscription regimes requires analysis that goes beyond the rationalist assumptions of positivist epistemologies, and instead traces the ways by which proscription-as an intervention for preferred outcomes in armed conflict-is coconstitutive, in non-linear ways, of identities, legitimacy, power relations, and even state sovereignty itself.

\section{Notes}

1. Meera Srinivasan, "Sri Lanka Bans 15 Tamil Diaspora Organisations," The Hindu, April 2, 2014, http://www.thehindu.com/news/international/south-asia/sri-lanka-bans-15-tamildiaspora-organisations/article5860193.ece.

2. "Diaspora Orgs Proscription Should Not Be Used to Stifle Free Speech and Legitimate Criticism, UK Tells Sri Lanka," Tamil Guardian, April 1, 2014, http://www.tamilguardian. com/content/diaspora-orgs-proscription-should-not-be-used-stifle-free-speech-andlegitimate-criticism-uk.

3. “Sri Lanka's Diaspora Ban Has 'No Legal Effect in Canada,"” Tamil Guardian, April 29, 2014, http://www.tamilguardian.com/content/sri-lankas-diaspora-ban-has-no-legal-effect-canadasays-foreign-affairs-minister.

4. Sarah Wayland, "Ethnonationalist Networks and Transnational Opportunities: The Sri Lankan Tamil Diaspora," Review of International Studies 30, no. 3 (2004): 405-26; International Crisis Group, "The Sri Lankan Tamil Diaspora after the LTTE," Asia Report $\mathrm{N}^{\circ} 186$, February 23, 2010. 
5. T. Ramakrishnan, "LTTE's Financial Network Still Intact: U.S. Report," The Hindu, June 21, 2015, http://www.thehindu.com/news/international/south-asia/lttes-financial-network-stillintact-us-report/article7337171.ece.

6. Oliver Walton, "Framing Disputes and Organizational Legitimation: UK-Based Sri Lankan Tamil Diaspora Groups' Use of the 'Genocide' Frame Since 2009," Ethnic and Racial Studies 38, no. 6 (2015): 959-75.

7. Suthaharan Nadarajah, "Disciplining the Diaspora: Tamil Self-Determination and the Politics of Proscription," in Alan Ingram and Klaus Dodds, eds., Spaces of Security and Insecurity: Geographies of the War on Terror (Farnham: Ashgate, 2009), 109-30; Victoria Sentas, Traces of Terror: Counter-terrorism Law, Policing, and Race (Oxford: Oxford University Press, 2014).

8. Claudia Aradau and Rens Van Munster, "Governing Terrorism through Risk: Taking Precautions, (Un)Knowing the Future," European Journal of International Relations 13, no. 1 (2007): 89-115; Marieke de Goede, "The Politics of Preemption and the War On Terror in Europe," European Journal of International Relations 14, no. 1 (2008): 161-85.

9. Eric Rosand, "Security Council Resolution 1373, the Counter-Terrorism Committee, and the Fight Against Terrorism," The American Journal of International Law 97, no. 2 (2003): 333-41.

10. United Nations, "Security Council Resolution 1373 (2001)" S/RES/1373 (2001), September 28, 2001. Emphases added.

11. Phil Miller, Exporting Police Death Squads: From Armagh to Trincomalee (Bremen: International Human Rights Association, 2015); Justin O. Smith, "Maritime Interdiction in Sri Lanka's Counterinsurgency," Small Wars \& Insurgencies 22 no. 3 (2011): 448-66; David Rampton and Suthaharan Nadarajah, "A Long View of Liberal Peace and its Crisis," European Journal of International Relations 23, no. 2 (2017): 441-65.

12. Sally Lipscombe, "The Terrorism Act 2000: Proscribed Organisations," House of Commons Library, July 25, 2014. SN/HA/00815, "U.S.: LTTE is not a Threat to Region or World," Tamil Guardian, December 15, 2006.

13. International Crisis Group, "Sri Lankan Tamil Diaspora" (see note 4).

14. Kent Roach, The 9/11 Effect: Comparative Counter-terrorism (New York: Cambridge University Press, 2011), 320-2, 381-4.

15. "Obituary: Anton Balasingham," The Times, December 14, 2006. https://www.thetimes.co.uk/ article/anton-balasingham-0c95qbtd28m.

16. Mark Duffield, Global Governance and the New Wars: The Merging of Development and Security (London: Zed Books Ltd., 2014); Adam Quinn and Michael Cox, "For Better, For Worse: How America's Foreign Policy Became Wedded to Liberal Universalism," Global Society 21, no. 4 (2007): 499-519.

17. Dvora Yanow, Conducting Interpretive Policy Analysis (Thousand Oaks, CA: Sage Publications, 1999).

18. See e.g., Gearóid ÓTuathail, "Theorizing Practical Geopolitical Reasoning: The Case of the United States' Response to the War in Bosnia," Political Geography 21, no. 5 (2002): 601-28.

19. See, e.g., Mark Neocleous, "The Police of Civilization: The War on Terror as Civilizing Offensive," International Political Sociology 5, no. 2 (2011): 144-59; Lee Jarvis and Tim Legrand, "Legislating for Otherness: Proscription Powers and Parliamentary Discourse," Review of International Studies 42, no. 3 (2016): 558-74; Mark Laffey and Suthaharan Nadarajah, "The Hybridity of Liberal Peace: States, Diasporas and Insecurity," Security Dialogue 43, no. 5 (2012): 403-20.

20. James Boyd White, "Law as Rhetoric, Rhetoric as Law: The Arts of Cultural and Communal Life," The University of Chicago Law Review 52, no. 3 (1985): 684-702.

21. See, e.g., Francis Fukuyama, The End of History and the Last Man (New York, NY: Simon and Schuster, 2006).

22. Laffey and Nadarajah, "Hybridity" (see note 19).

23. Michael Klare, "East-West Versus North-South: Dominant and Subordinate Themes in U.S. Military Strategy since 1945," in John R. Gillis, ed., The Militarization of the Western World (New Brunswick: Rutgers University Press, 1989), 141-65. 
24. Duncan Bell, “What Is Liberalism?," Political Theory 42, no. 6 (2014): 682-715; Beate Jahn, "The Tragedy of Liberal Diplomacy: Democratization, Intervention and Statebuilding (Part I)," Journal of Intervention and Statebuilding 1, no. 1 (2007): 87-106.

25. Meera Sabaratnam, "The Liberal Peace? A Brief Intellectual History of International Conflict Management, 1990-2010," in Susanna Campbell and others, eds., A Liberal Peace? The Problems and Practices of Peacebuilding (London: Zed Books, 2011), 13-30.

26. Quinn and Cox, "For Better or Worse" (see note 16), 500.

27. Duffield, Global Governance (see note 16); Rampton and Nadarajah, "A Long View" (see note 11).

28. Oliver P. Richmond, The Transformation of Peace (Basingstoke: Palgrave Macmillan, 2007), 13.

29. Neocleous (see note 19).

30. Laffey and Nadarajah, "Hybridity" (see note 19).

31. David Chandler, "International Justice," New Left Review 6 (2000): 55-66.

32. See, e.g., Neocleous (see note 19); Jarvis and Legrand (see note 19).

33. Roach (see note 14), 13.

34. Jessie Blackbourn, “The Evolving Definition of Terrorism in UK Law," Behavioral Sciences of Terrorism and Political Aggression 3, no. 2 (2011): 131-49.

35. Ibid., 139-41.

36. Ibid.

37. Ibid., 140 .

38. Ibid., 143.

39. U.S. State Department, "Foreign Terrorist Organizations," Undated, Emphasis added, https:// www.state.gov/j/ct/rls/other/des/123085.htm.

40. V. S. Sambandan, "A Message from Washington," Frontline, May 9, 2003, Emphases added, http://www.frontline.in/static/html/fl2009/stories/20030509002204900.htm.

41. "U.S. Will Play its Part for Peace in Sri Lanka-Armitage," Daily News, November 27, 2002, Emphases added, http://archives.dailynews.lk/2002/11/27/new05.html.

42. Laffey and Nadarajah, "Hybridity" (see note 19).

43. U.S. State Department, "Foreign Terrorist Organizations," Undated, Emphasis added, https:// www.state.gov/j/ct/rls/other/des/123085.htm.

44. See, e.g., Christina Pantazis and Simon Pemberton, "From the 'Old' to the 'New' Suspect Community: Examining the Impacts of Recent UK Counter-terrorist Legislation," British Journal of Criminology 49, no. 5 (2009): 646-66.

45. See, e.g., Véronique Dudouet, "Anti-terrorism Legislation: Impediments to Conflict Transformation," Berghof Policy Brief 02, November 2011; Sara Pantuliano and others, "Counter-terrorism and Humanitarian Action," Policy Brief 43, Humanitarian Policy Group, October 2011.

46. See, e.g., Sentas, “Traces of Terror" (see note 7); Mark Muller, “Terrorism, Proscription, and the Right to Resist in the Age of Conflict," Denning Law Journal 20, no. 1 (2008): 111-31.

47. See, e.g., Mark Duffield, "Getting Savages to Fight Barbarians: Development, Security and the Colonial Present: Analysis,” Conflict, Security \& Development 5, no. 2 (2005): 141-59.

48. Kimberly Hutchings, "Liberal Quotidian Practices of World Ordering," in Tim Dunne and Trine Flockhart, eds., Liberal World Orders (Oxford: Oxford University Press, 2013), 162.

49. Wendy Larner, "Neo-liberalism: Policy, Ideology, Governmentality," Studies in Political Economy 63, no. 1 (2000): 5-25.

50. Mitchel Dean, Governmentality: Power and Rule in Modern Society (London: Sage Publications, 2010).

51. White (see note 20), 683.

52. Ibid.

53. Ibid., 684 .

54. Ibid., 691.

55. Ibid.

56. Ibid., 689. 
57. Ibid., 698. Emphases added.

58. Ibid. Emphases added.

59. See, e.g., Pantazis and Pemberton (see note 44); Jarvis and Legrand (see note 19); Nadarajah, "Disciplining the Diaspora" (see note 7).

60. White (see note 20), 684. Emphases added.

61. Ibid., 690.

62. Neil DeVotta, Blowback: Linguistic Nationalism, Institutional Decay, and Ethnic Conflict in Sri Lanka (Stanford, CA: Stanford University Press, 2004); Sankaran Krishna, Postcolonial Insecurities: India, Sri Lanka, and the Question of Nationhood (Minneapolis, MN: University of Minnesota Press, 1999); Madurika Rasaratnam, Tamils and the Nation: India and Sri Lanka Compared (London: Hurst \& Co., 2016).

63. Suthaharan Nadarajah and Dhananjayan Sriskandarajah, "Liberation Struggle or Terrorism? The Politics of Naming the LTTE," Third World Quarterly 26, no. 1 (2005): 87-100.

64. International Commission of Jurists, "Authority Without Accountability: The Crisis of Impunity in Sri Lanka” (November 2012).

65. "Sri Lanka President Vows to Eradicate LTTE Ideology," The Hindu, June 8, 2016, http:// www.thehindu.com/news/international/south-asia/sri-lanka-president-maithripala-sirisenavows-to-eradicate-ltte-ideology/article8705092.ece.

66. Miller (see note 11), 6.

67. Ibid.

68. Rampton and Nadarajah, "A Long View” (see note 11).

69. Ibid.

70. "Press conference in Sri Lanka," Margaret Thatcher Foundation, April 12, 1985. http://www. margaretthatcher.org/document/106022.

71. "R. Nicholas Burns, Under Secretary for Political Affairs: Remarks to the Press in Sri Lanka," U.S. State Department, January 23, 2006, https://2001-2009.state.gov/p/us/rm/2006/59562. htm.

72. Rasaratnam (see note 62), 180.

73. Miller (see note 11), 9.

74. Author interviews with Tamil activists, London, June 2009.

75. Daniel Byman and others, Trends in Outside Support for Insurgent Movements (Santa Monica, CA: RAND National Security Research Division, 2001).

76. Nadarajah, "Disciplining the Diaspora" (see note 7).

77. Kristian Stokke, "Building the Tamil Eelam State: Emerging State Institutions and Forms of Governance in LTTE-controlled Areas in Sri Lanka," Third World Quarterly 27, no. 6 (2006): 1021-40.

78. Mark Salter, To End a Civil War: Norway's Peace Engagement in Sri Lanka (London: Hurst \& Co., 2015).

79. Jeffrey Lunstead, The United States' Role in Sri Lanka Peace Process 2002-2006 (Colombo: The Asia Foundation, 2007), 17-18.

80. Brian Blodgett, Sri Lanka's Military: The Search for a Mission (San Diego, CA: Aventine Press, 2004).

81. Smith, "Maritime Interdiction" (see note 11).

82. See discussion below of the UK's sole LTTE-related terrorism prosecution (2007-9).

83. Nadarajah, "Disciplining the Diaspora" (see note 7).

84. Smith, "Maritime Interdiction" (see note 11).

85. "British Envoy Banned in War Without Witnesses," The Independent, February 14, 2009. http://www.independent.co.uk/news/world/asia/british-envoy-banned-in-war-withoutwitnesses-1609188.html.

86. United Nations, Report of the OHCHR Investigation on Sri Lanka (OISL), September 16, 2015. http://www.ohchr.org/EN/HRBodies/HRC/RegularSessions/Session30/Documents/A_ HRC_30_CRP_2.docx. 
87. Randeep Ramesh, "Sri Lanka Rejects International Call for Ceasefire with Tamil Tigers," The Guardian, February 5, 2009. https://www.theguardian.com/world/2009/feb/05/sri-lankaceasefire-tamil-tigers.

88. "Britain and France Fail to Persuade Sri Lanka to End War," Daily Telegraph, April 29, 2009. http://www.telegraph.co.uk/news/worldnews/asia/srilanka/5242076/Britain-and-France-failto-persuade-Sri-Lanka-to-end-war.html.

89. "POTUS to Speak on Situation in Sri Lanka," Fox News, May 13, 2009. http://www.foxnews. com/politics/2009/05/13/potus-to-speak-on-situation-in-sri-lanka.html.

90. United Nations, Report of the Secretary General's Panel of Experts on Accountability in Sri Lanka, March 31, 2011. http://www.un.org/News/dh/infocus/Sri_Lanka/POE_Report_Full. pdf;.

91. United Nations, Report of the OHCHR Investigation (see note 86).

92. "No Congratulations from the U.S. on Sri Lanka's Victory over LTTE," ColomboPage, May 19, 2009. http://www.colombopage.com/archive_091/May1242693009CH.html.

93. See, e.g., International Crisis Group, "Reconciliation in Sri Lanka: Harder than Ever," Asia Report No209, July 18, 2011.

94. Rasaratnam (see note 62), 221-26.

95. “Tamil Protest at Parliament Square-Financing Additional Costs," Metropolitan Police Authority, June 18, 2009. http://policeauthority.org/Metropolitan/committees/finres/2009/ 090618/08/index.html.

96. "British-based Sri Lankan Jailed for Helping Tamil Tigers in Terror Attacks," The Daily Telegraph, June 12, 2009. http://www.telegraph.co.uk/news/uknews/5517148/British-basedSri-Lankan-jailed-for-helping-Tamil-Tigers-in-terror-attacks.html.

97. Rasaratnam (see note 62), 221-26.

98. Walton, "Framing Disputes" (see note 6).

99. "Certain Western Countries Trying to Divide Country," Daily News, March 12, 2012. http:// archives.dailynews.lk/2012/03/12/news32.asp.

100. "Tamil Guardian, "Diaspora Orgs" (see note 2).

101. "UK, Australia and Canada Caution Tamil Citizens over Sri Lanka's Terror Laws after Diaspora Bans," Tamil Guardian, April 12, 2014. http://www.tamilguardian.com/content/ukaustralia-and-canada-caution-tamil-citizens-over-sri-lankas-terror-laws-after-diaspora.

102. "UK Welcomes Sri Lanka Delisting Proscribed Organizations," ColomboPage, November 22, 2015, http://www.colombopage.com/archive_15B/Nov22_1448209700CH.php.

103. Ramakrishnam (see note 5).

104. "LTTE Remains a Terrorist Organisation: EU," Daily Mirror, July 26, 2017. http://www. dailymirror.lk/133606/LTTE-remains-a-terrorist-organisation-EU.

105. White (see note 20), 684 .

\section{Notes on contributor}

Suthaharan Nadarajah is a lecturer in International Relations in the Centre for International Studies and Diplomacy at SOAS University of London. His research focusses on international security, global governance, and North-South relations. His work has appeared in the European Journal of International Relations, Review of International Studies, Security Dialogue, and Third World Quarterly. 